\title{
Sedimentary characterization of the carbonate source rock of Upper Kimmeridgian Parnac Formation of the Aquitaine Basin (Quercy area)
}

\author{
Laura Bastianini ${ }^{1, *}$, Bruno Caline ${ }^{1}$, Guilhem Hoareau ${ }^{2}$, Cédric Bonnel $^{2}$, Mathieu Martinez ${ }^{3}$, \\ Carine Lézin ${ }^{4}$, François Baudin ${ }^{5}$, Alexander Brasier ${ }^{6}$ and Laurent Guy ${ }^{7}$ \\ 1 Total SA, Centre Scientifique Jean Féger, Avenue Larribau, 64018 Pau Cedex, France \\ 2 LFC-R, UMR 5150, Université de Pau et des Pays de l'Adour, Pau Cedex, France \\ ${ }^{3}$ MARUM - Center for Marine Environmental Sciences, Leobenerstrasse 8, University of Bremen, 28359 Bremen, Germany \\ ${ }^{4}$ Géosciences Environnement Toulouse (GET), Observatoire Midi Pyrénées, Université de Toulouse, CNRS, IRD, 14 avenue E. Belin, \\ 31400 Toulouse, France \\ 5 ISTeP, UMR 7193, Université Pierre et Marie Curie, Paris, France \\ ${ }^{6}$ University of Aberdeen, School of Geosciences, Meston Building, Old Aberdeen, AB24 3UE, Aberdeen, UK \\ 7 TOTAL SA, Centre Scientifique Jean Féger, Avenue Larribau, 64018 Pau Cedex, France
}

\begin{abstract}
The main source rock (SR) of the Aquitaine Basin, the most important oil province in France, corresponds to organic-rich marine limestones of Upper Kimmeridgian age (Lons Formation in the Béarn area and Parnac Formation in the Quercy area). In order to better characterize their depositional environment, in particular the conditions of accumulation and preservation of organic-matter, a sedimentological, micropaleontological and geochemical study of the Crayssac section (Quercy) has been performed. Organic-rich sediments are argillaceous limestones (65 to $99 \% \mathrm{CaCO}_{3}$ ) organized in repetitive beds of up to $1-\mathrm{m}$ thickness. Their total organic matter content reaches up to $15 \mathrm{wt} . \%$, and in this SR kerogen is type of II and immature. Microfauna content, the lack of barrier facies and the control of the wave action base over the depositional environments reflect deposition in an open marine type homoclinal ramp. Strong similarities with Kimmeridgian organic-rich limestones of the Middle East (Hanifa Formation) suggest that the Parnac Formation could act as an analogue of this prolific SR.
\end{abstract}

Keywords: Aquitaine Basin / source rock / Upper Kimmeridgian / Parnac Formation / carbonates / organic matter

Résumé - Caractérisation sédimentaire de la formation roche mère carbonatée Parnac du Kimméridgien supérieur du Bassin d'Aquitaine (Quercy). La principale roche mère du Bassin aquitain, première province pétrolière française, correspond à des roches marno-calcaires marines d'âge Kimméridgien supérieur (Formations de Lons dans le Béarn et de Parnac dans le Quercy). Afin de caractériser l'environnement de dépôt de la Formation Parnac, en particulier les conditions d'accumulation et de préservation de la matière organique, une étude sédimentologique, micropaléontologique et géochimique de la coupe de Crayssac (Quercy) a été réalisée. Les sédiments riches en matière organique sont des calcaires argileux (65 à $99 \%$ de $\left.\mathrm{CaCO}_{3}\right)$ organisés en une succession de bancs d'épaisseur atteignant 1 mètre. Leur concentration en carbone organique total s'élève jusqu'à $15 \%$, et dans cette roche mère les kérogènes sont de type II et immatures. La microfaune, l'absence de faciès de barrière et le contrôle de la profondeur d'action des vagues sur les environnements de dépôts avec une graduation régulière indiquent que l'environnement de dépôt de cette formation roche mère est de type marin ouvert sur une rampe homoclinale. Les fortes similitudes avec les calcaires argileux riches en matière organique de la formation roche mère du Kimméridgien au Moyen-Orient (Formation Hanifa) suggèrent que la Formation Parnac constitue un analogue de cette roche mère prolifique.

Mots clés : Bassin d'Aquitaine / roche mère / Kimméridgien supérieur / Formation de Parnac / carbonates / matière organique

\footnotetext{
*Corresponding author: bastianinilaura@hotmail.fr
} 


\section{Introduction}

In the context of increasing unconventional oil and gas exploration, carbonate petroleum SR (SR) are of special interest for the oil industry due to their commonly high prolific character (Murris, 1980; Droste, 1990). Much effort is needed to better constrain their conditions of organic matter accumulation and preservation, which are still largely debated (Harris and Katz, 2005; Myers, 2009). One of the best-known examples of carbonate SR is the Upper Jurassic Hanifa Formation (Fm) (Upper Oxfordian/Lower Kimmeridgian, Gulf of Arabia), which is one of the most prolific SR in the world (Alsharhan and Magara, 1994; Poppelreiter et al., 2012). This Formation comprises organic-rich argillaceous limestone beds (Gotnia Basin) which pass laterally into calcareous shales (Qatar Arch) (Poppelreiter et al., 2012). It was set up within an intra-shelf basin on a wide epeiric shallow-water carbonate platform under anoxic conditions and organic carbon content can be greater than $13 \%$, with generation potential of $90 \mathrm{mg}$ $\mathrm{HC} / \mathrm{g}$ rock (Droste, 1990). The source interval has a cyclic character and can exceed 170-m thick (Poppelreiter et al., 2012). Accordingly, massive hydrocarbon generation in the Hanifa Fm has sourced several world-class reservoirs of the Middle East, such as Upper Jurassic Arab and Lower Cretaceous Thamama reservoirs in offshore Abu Dhabi (Beydoun, 1986), and Upper Jurassic Hanifa reservoir at the Abqaiq and Berri Fields, Saudi Arabia (Alsharhan and Magara, 1994). Paradoxically, the depositional conditions and geochemistry of the Hanifa Fm remain to be investigated in detail, due in particular to the scarcity of wells crossing this SR (e.g., Harris and Katz, 2005; Myers, 2009).

The Lons Limestones Formation, the main SR of the Aquitaine Basin (France) petroleum system, is also characterized by high carbonate content (Hantzpergue and Lafaurie, 1983; Hantzpergue, 1987; Cubaynes et al., 1989), which makes it a potential analogue of the Hanifa Formation. The Lons Limestones Formation outcrops south and north of the basin, making its study easy from field observations and sampling. In order to evaluate potential analogies between Lons Limestones and Hanifa Formations, a sedimentological, mineralogical and geochemical study was carried out on a referential outcrop from the Quercy area (NE Aquitaine Basin), in the Parnac Formation, a local equivalent of the Lons Limestones Formation. This integrated approach is used to build a depositional model and a preliminary interpretation in terms of sequence stratigraphy, as well as to determination the origin and quality of organic matter.

\section{Geological context}

The Aquitaine Basin (SW France), which extends over $66000 \mathrm{~km}^{2}$, is open to the west on the Atlantic margin, bordered to the north by the Armorican Massif, to the northeast by the Massif Central, to the east by the Montagne Noire, and to the south by the Pyrenees. It can be divided into three zones: to the north, a stable margin overlying the Hercynian basement, in the median part, the subsiding area of Parentis-Quercy (Fig. 1) and to the south, the Pyrenean foredeep.

The Aquitaine Basin opened during a phase of continental rifting (Fig. 2), developed from the Triassic to the Early Liassic and marked by the deposition of a thick evaporitic sequence (Bilotte, 1995; Biteau et al., 2006). During the Middle Jurassic, it was filled by marine, fine terrigenous deposits alternating with coarse-grained carbonates, in the context of the early opening of the Atlantic Ocean (BRGM, 1986). In the Middle Jurassic, the Aquitaine Basin formed a wide shallow carbonate platform (Canerot and Lenoble, 1989). Three areas can be differentiated from west to east: an outer platform with marl facies, an oolitic barrier and an inner platform that was locally confined (Canerot and Lenoble, 1989). Jurassic sedimentation ended with a first-order regression, the so-called "Purbeckian" regression (Berriasian; [Hardenbol et al., 1998]) characterized by shallow marine to restricted environments (e.g., Schnyder et al., 2012). This regression resulted in individualization of small confined areas during the early Cretaceous (Charentes, Quercy, Parentis, and Adour areas) (BRGM, 1986; Cubaynes et al., 2004). The Pyrenean orogeny, which started in the Lower Eocene and accentuated during the Eocene, involved positive topographic readjustments and erosion in the Massif Central (BRGM, 1986). In the Early Miocene, a shallow sea still covered the area of Agen where shorelines developed and the Miocene was marked by the Alpine compression (BRGM, 1986). At the end of the Miocene, the Aquitaine Basin was essentially filled (BRGM, 1986; Cubaynes et al., 2004). The sedimentary record reaches 500 to 2000 meters in the northAquitaine platform (Charente, Périgord, Quercy), 4000 to 6000 meters in the northern basin of the Landes region, and finally 8000 meters in the southern Aquitaine rift valley between Pau and Audignon (Cubaynes et al., 2004).

The main SR formations of the Aquitaine Basin were deposited during the Pliensbachian-Toarcian (Lias Marls Fm.) and the Kimmeridgian (Lons Limestones Fm. and Lituolidae Limestones Fm.), in two first-order transgression intervals (Hardenbol et al., 1998; Biteau et al., 2006).

This study focuses on the Crayssac section as part of the Quercy area, where several exposures of Kimmeridgian organic-rich carbonates can be observed (Delfaud, 1969; Pélissié, 1982). This 77-m-thick section consists of four lithological groups (Pélissié, 1982) (Fig. 1). To the base, the first one consists in nodular limestone alternating with massive and argillaceous limestone, corresponding to the Pont de Rhodes and the St Martin de Vers Formations, as well as the lower part of the Parnac Formation, which is crowned by the Caletanum horizon (Hantzpergue, 1987; Cubaynes et al., 2004). The second group comprises the upper part of the Parnac Formation and includes the SR of interest in this study. It is made of argillaceous limestone layers of variable organicmatter content and characterized by vertebrate fauna (Steneosaurus sp.) (Hantzpergue and Lafaurie, 1983). It is covered by 23 meters of argillaceous limestone also locally rich in organic matter (Saint-Chamarand Fm). Finally, the upper lithological group consists of limestone of the Salviac Formation (Delfaud, 1969; Cubaynes et al., 1989) (Figs. 3-5).

\section{Material and methods}

\subsection{Field-work methods}

A total of 123 samples were taken along the section with a sample distance of $c a .0 .50 \mathrm{~m}$ for further analyses in the laboratory. In addition, a total gamma-ray profile was surveyed 


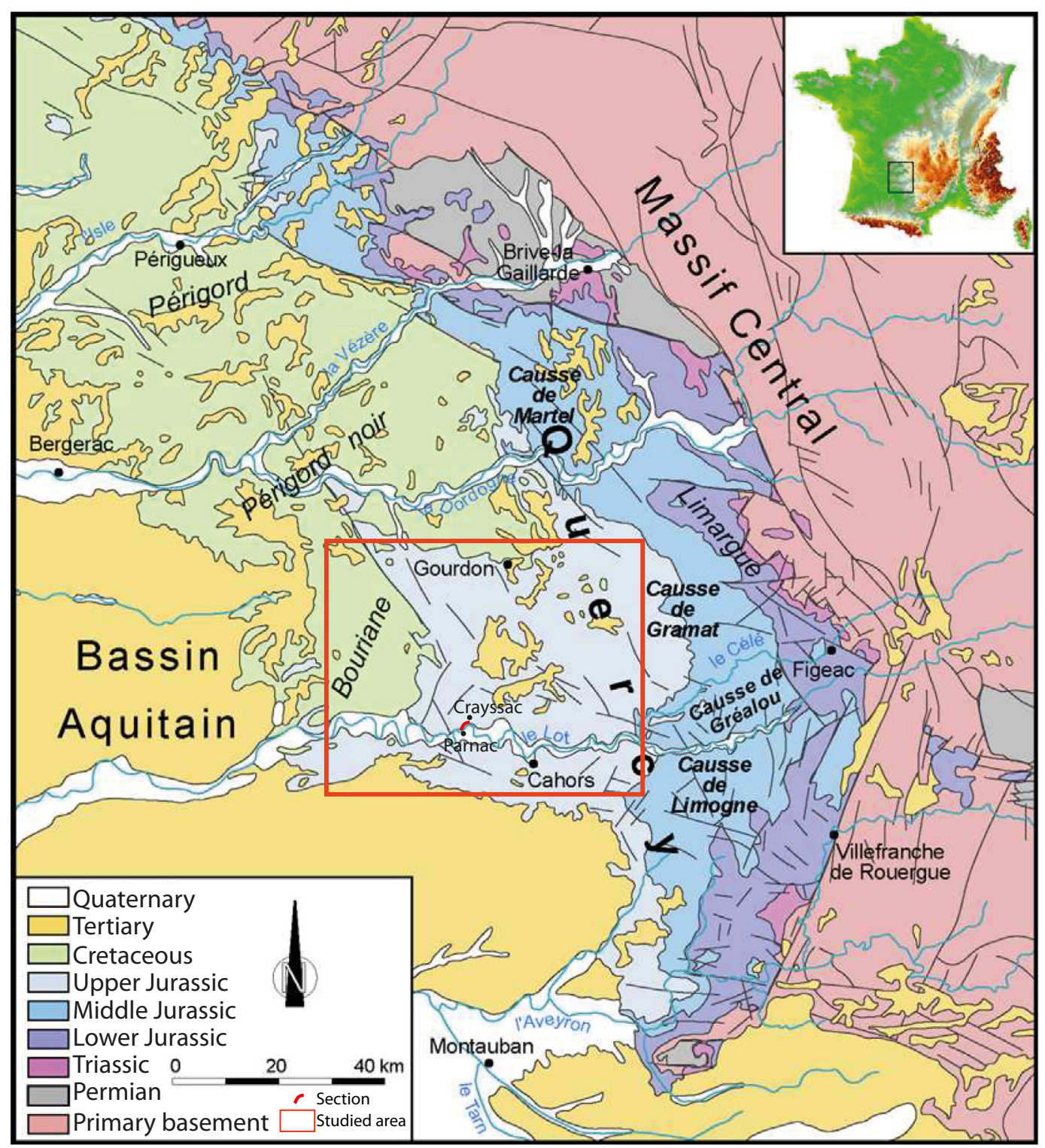

Fig. 1. Geological map of the Quercy (modified after Astruc et al., 2008).

along 77 meters of the section mostly in the Parnac Formation ( 77 samples with a step of $0.50 \mathrm{~m}$ ) (Figs. 4 and 5). Spectral gamma-ray measurements used a nanoSPEC apparatus (Aries). Spectral gamma-ray quantifies the gamma emission from ${ }^{40} \mathrm{~K},{ }^{235} \mathrm{U}$ and ${ }^{232} \mathrm{Th}$, the three main natural gamma-ray sources (Serra, 1979). These three radioisotopes are commonly concentrated in the continental crust and exported with the clays to the basin during continental alteration (Quirein et al., 1982). In addition, uranium is an organophile element and is found in abundance in organic-rich sediments (Schmoker, 1981). Potassium and thorium are usually concentrated in clayey sediments, while uranium is concentrated in organicrich sediments (Schmoker, 1981; Quirein et al., 1982). Each measurement was performed with a constant acquisition time of 60 seconds. Each point was measured after the surface had been cleaned from weathered sediments and smoothed in order to avoid border effects (Huret, 2006). Each point was measured three times to assess the reproducibility of the measurements.

\subsection{Laboratory analyses}

A petrographic and micropaleontogical study of limestones and argillaceous limestones was performed on 48 thin sections produced from selected samples, using conventional microscopy in order to determine the mineralogy, texture and micro fauna for depositional environment characterization.

Five bulk rock samples corresponding to distinct facies of the Crayssac section were analysed with a Scanning Electron Microscope (Hitachi S4700) to identify the micro-texture of the most organic-matter-rich facies at the Centre Scientifique et Technique Jean-Féger (TOTAL SA, Pau, France).

Bulk rock and clay mineralogy of 30 powdered samples were acquired by X-ray diffraction (XRD) using $\mathrm{CoK} \alpha$ radiations at the Laboratoire Géosciences Environnement de Toulouse (GET, France). For bulk rock data, XRD measurements were performed on disoriented powder preparations. For clay minerals, data were acquired on oriented mounts of 


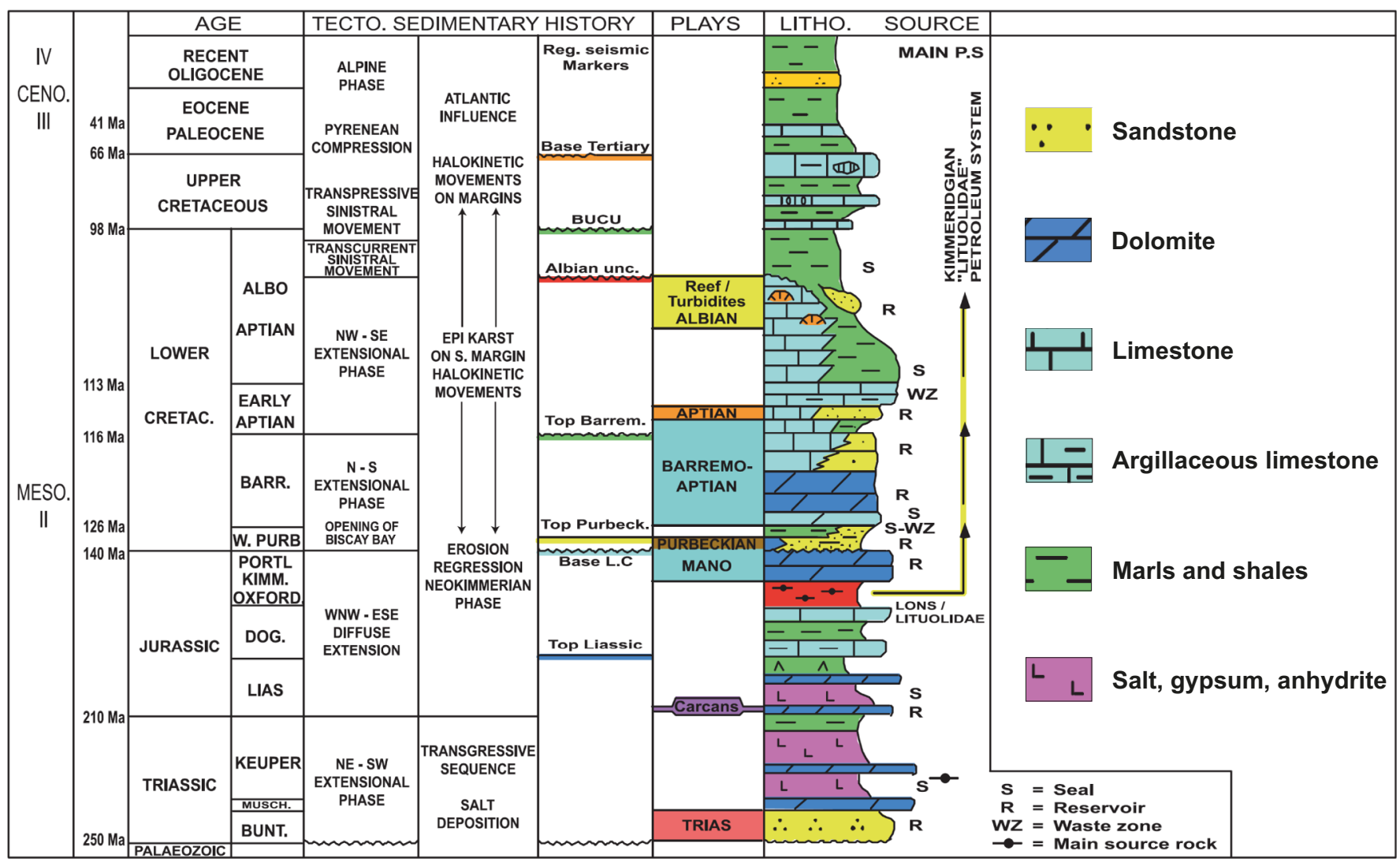

Fig. 2. Geological context of the Aquitaine Basin (Biteau et al., 2006).

non-calcareous clay-sized particles $(2 \mu \mathrm{m})$. After removing carbonate using $0.2 \mathrm{~N} \mathrm{HCl}$, deflocculation of clays was completed by repeated washing with distilled water. Particles finer than $2 \mu \mathrm{m}$ were concentrated by centrifugation. The first XRD run was performed after air-drying, the second after ethylene-glycol solvation, and the third after heating at $550^{\circ} \mathrm{C}$ for 2 hours.

Calcimetry was performed at the Laboratoire des Fluides Complexes et leurs Réservoirs (Pau, France) on 30 powdered samples following the volumetric method employing a Bernard calcimeter (Lamas et al., 2005) (accuracy of $\pm 3 \%$ ).

Rock-Eval pyrolysis (Espitalié et al., 1977) was made on 73 powdered samples, using a Rock Eval 6 (VINCI Technologies) at the ISTeP (Paris, France). From Rock-Eval analyses, it is possible to obtain the quantity of free hydrocarbons ( $\mathrm{S} 1$, in $\mathrm{mg} / \mathrm{g}$ of rock), the quantity of thermally generated cracked hydrocarbons ( $\mathrm{S} 2$, in $\mathrm{mg} / \mathrm{g}$ of rock), the quantity of $\mathrm{CO}_{2}$ generated during pyrolysis of the sample ( $\mathrm{S} 3$, in $\mathrm{mg} / \mathrm{g}$ of rock), the Hydrogen Index (HI, in $\mathrm{mg} / \mathrm{g}$ of rock), the Oxygen Index (OI, in $\mathrm{mg} \mathrm{CO}_{2} / \mathrm{g} \mathrm{TOC}$ ), and temperature at which the largest quantity of hydrocarbons is released upon cracking (Tmax). The inorganic carbon content obtained with the technique was converted into carbonate content $\left(\% \mathrm{CaCO}_{3}\right)$.

\section{Results}

A synthetic sedimentological log of the Crayssac section, which includes faunal content, gamma ray and geochemical results, is presented in Figures 3-5.

\subsection{Calcimetry data}

The calcimetry data from Figures 4 and 5 show that the content in $\mathrm{CaCO}_{3}$ ranges from $65 \%$ to $100 \%$. The clay or marl fraction is therefore always a secondary component. The studied rocks thus correspond to argillaceous limestones and limestones.

\subsection{Macroscopic description}

Field observations allow to distinguish the different facies observed in the Crayssac section between five distinct macrofacies: massive limestone (Fig. 6A), nodular limestone (Fig. 6B), bioclastic limestone (Fig. 6C), argillaceous limestone (Fig. 6D), and organic-matter-rich argillaceous limestone (Fig. 6E and F). All limestones are light beige except the organic-matter-rich one which is brown. Massive, bioclastic and argillaceous limestones are compact and lack clear sedimentary structures, whereas organic matter-rich argillaceous limestone is laminated.

\subsection{Optical petrography}

Microfacies characterization of massive limestone allows to define it as a bioclastic mudstone. It includes the presence of large fragments of bivalves, sponge spicules, benthic foraminifera with hyaline test (Epistomina sp., Lenticulina sp.), some gastropods, rare fragments of echinoderms and abundant pyrite (Fig. 7B and F). 


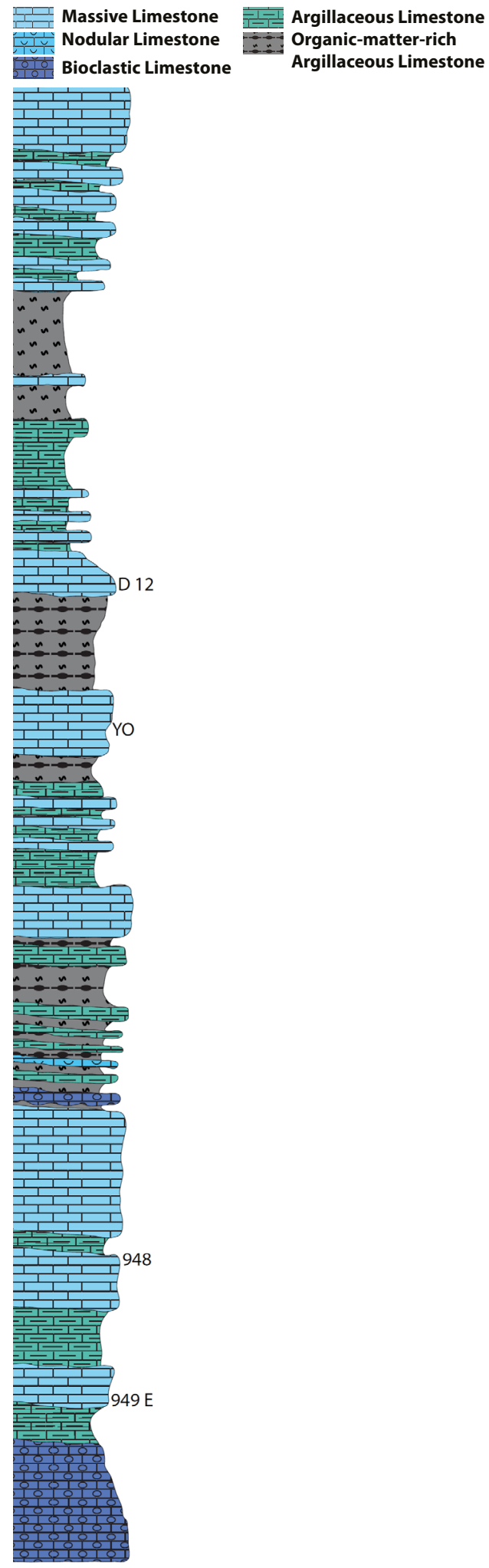

Fig. 3. Section lithology of Crayssac.

Bioclastic limestone microfacies corresponds to a bioclastic wackestone, comprising large, perforated, and lightly micritised bioclasts (Fig. 7F). The faunal content is marked by the predominant presence of bivalve fragments, and of some gastropod and echinoderm fragments, as well as benthic foraminifera. The latter have mainly agglutinated test (Conicospoirillina sp., Everticyclammina virguliana), and more rarely hyaline test (Lenticulina sp.) (Fig. 7B).

Nodular limestone corresponds to a bioclastic wackestone with abundant microbioclasts, large fragments of bivalves, gastropods, echinoderms, pyrite, numerous benthic foraminifera with agglutinated test (Rectocyclammina chouberti, Everticyclammina virguliana) and some with hyaline test (Lenticulina sp.) (Fig. 7B, D and E).

Argillaceous limestone can be classified as a mudstone/ wackestone. Its faunal content is composed of bivalve fragments, benthic foraminifera with agglutinated (Everticyclammina virguliana) and hyaline tests (Lenticulina sp.), sponge spicules, serpula, some microbioclasts, and rare fragments of echinoderms (Fig. 7A, B and D). All bioclasts have been altered during diagenesis. Pyrite is found in abundance.

The organic-matter-rich limestone corresponds to a wackestone with bioclasts of bivalves, locally filled with peloids, and echinoderms. It is also composed of benthic foraminifera with hyaline test (Fondicularia sp.) (Fig. 7H), and presents numerous iron oxide grains. The fauna in this facies was shattered and transported. It is therefore reworked.

\subsection{Sample examination by SEM}

Five samples representative of the different macro-facies have been studied (Fig. 8), using both the classification of Volery et al. (2010) focused on the different types of intercrystalline contacts in the micrites, and the classification of de Périère et al. (2011) focused on micritic microtextures.

Massive limestone (sample 3-1-a; $\mathrm{CaCO}_{3}=99 \%$ ) has a micritic matrix composed of coarse, heterogeneous grains $(\sim 2.7 \mu \mathrm{m}$ in size), surrounding rare bioclastic components (Fig. 8A). Micrite grains are sub-euhedral to rhombohedral with tight intercrystalline contacts, resulting in low intercrystalline microporosity. Rhombohedral crystals likely result from recrystallization of former micrite (Volery et al., 2010). Drusy calcite cement is also locally observed.

Bioclastic limestone (sample 3-1-b; $\mathrm{CaCO}_{3}=95 \%$ ) has a more crystalline micritic matrix with coarse, heterogeneous anhedral grains $(\sim 2.7 \mu \mathrm{m}$ in size $)$, which are angular with intercrystalline tangential contacts (Fig. 8B). Evidence of partial grain dissolution likely explains good apparent intercrystalline porosity. Large rhombohedral dolomite grains, which are partially dissolved, are locally observed.

Nodular limestone (sample 3-1-c; $\mathrm{CaCO}_{3}=90 \%$ ) present micrite and composed of fine homogeneous micrite grains $(\sim 1.7 \mu \mathrm{m}$ in size) (Fig. 8C). Particles are flattened, with crushed intercrystalline contacts and evidence of secondary precipitation of calcite platelets. This sample has a very low intercrystalline microporosity.

Argillaceous limestone (sample 3-1-d; $\mathrm{CaCO}_{3}=85 \%$ ) has a matrix made of coarse, heterogeneous micrite $(\sim 2.7 \mu \mathrm{m}$ in size) and clays in the form of rounded sheets and platelets (Fig. 8D). Most micrite grains are subhedral to anhedral with coalescent intercrystalline contacts, but some particles have scalenohedral morphologies. Intercrystalline microporosity is very low. 


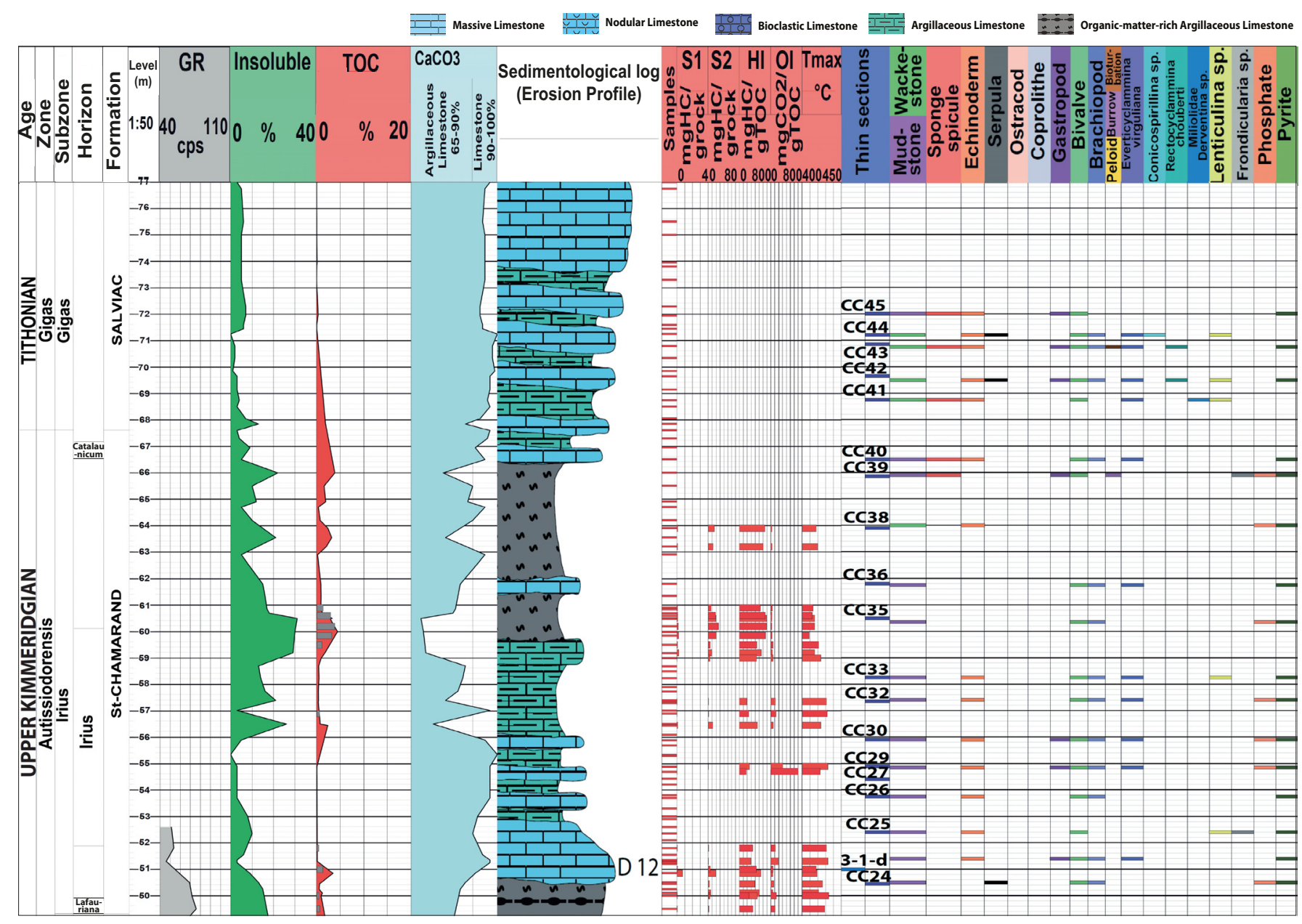

Fig. 4. Synthetic sedimentological log of Crayssac with gamma-ray, calcimetry, geochemistry data and the biostratigraphic wedge and fauna content (Salviac and St-Chamarand Formations).

Organic-matter-rich argillaceous limestone (sample 3-1-e: $\mathrm{CaCO}_{3}=82 \%$; $\mathrm{TOC}=5.2 \%$ ) shows fine, angular and homogeneous micrite (1.6 $\mu \mathrm{m}$ in size) (Fig. 8E). Micrite grains are mainly subhedral with tight intercrystalline contacts, resulting in very low intercrystalline microporosity.

\subsection{Rock-Eval Pyrolysis}

Most limestone samples have a TOC lower than $1 \%$ and a strong OI ( $>100 \mathrm{mg} \mathrm{CO}_{2} / \mathrm{g}$ TOC), and as such cannot be classified as SR (Figs. 4 and 5). Samples with a high OI could have either been altered by oxidation during depositing or exhumation (Espitalié et al., 1985). Alternatively, high OI may be an artefact of high $\mathrm{CaCO}_{3}$ and low TOC contents $(<3 \%)$ (Espitalié et al., 1985). Most organic-matter-rich argillaceous limestones and part of argillaceous limestones have high TOC (2 to $15 \%$ ), and important $\mathrm{HI}$ values of up to $700 \mathrm{mgHC} / \mathrm{gTOC}$ (Fig. 6). In these lithologies, $\mathrm{S} 1$ values reach up to $4 \mathrm{mg} \mathrm{HC} / \mathrm{g}$ rock and $\mathrm{S} 2$ values reach up to $80 \mathrm{mg} \mathrm{HC} / \mathrm{g}$ rock (Figs. 4 and 5). Finally, Tmax values are on average lower than $430{ }^{\circ} \mathrm{C}$, indicating that the organic matter suffered a very limited thermal alteration and is still immature with respect to the oil generation.

\subsection{Gamma-ray spectrometry}

Gamma-ray values range from 40 to 110 counts per second (cps), with an average of $71 \mathrm{cps}$ (Figs. 4 and 5). From $15 \mathrm{~m}$ to $32.5 \mathrm{~m}$, the gamma-ray signal first shows an interval of high values (average $=78 \mathrm{cps}$ ). Then, the values sharply decrease and remain lower up to the top of the series (average $=66 \mathrm{cps}$ ). The gamma-ray series roughly covaries with the insoluble fraction and TOC (Figs. 4 and 5). This is particularly obvious in the upper interval (from $32.5 \mathrm{~m}$ upward), in which the peaks of gamma-ray values at $36 \mathrm{~m}, 41 \mathrm{~m}$ and $47 \mathrm{~m}$ correspond to maximum values in insoluble fraction. In the lower interval, however, peaks of gamma-ray values at $19-21 \mathrm{~m}$ and $32.5 \mathrm{~m}$ are not associated to maximum values in neither insoluble fraction nor TOC.

\subsection{Analyses of X-Ray Diffraction}

These XRD analyses led to three different types of diffractograms. The first type, which includes most samples (12 of 16), indicates the presence of calcite $(95 \%)$, clay $(4 \%)$ and minor quartz (1\%). Clay minerals mainly contain illite + mica, a swelling phase of illite-smectite, and kaolinite 


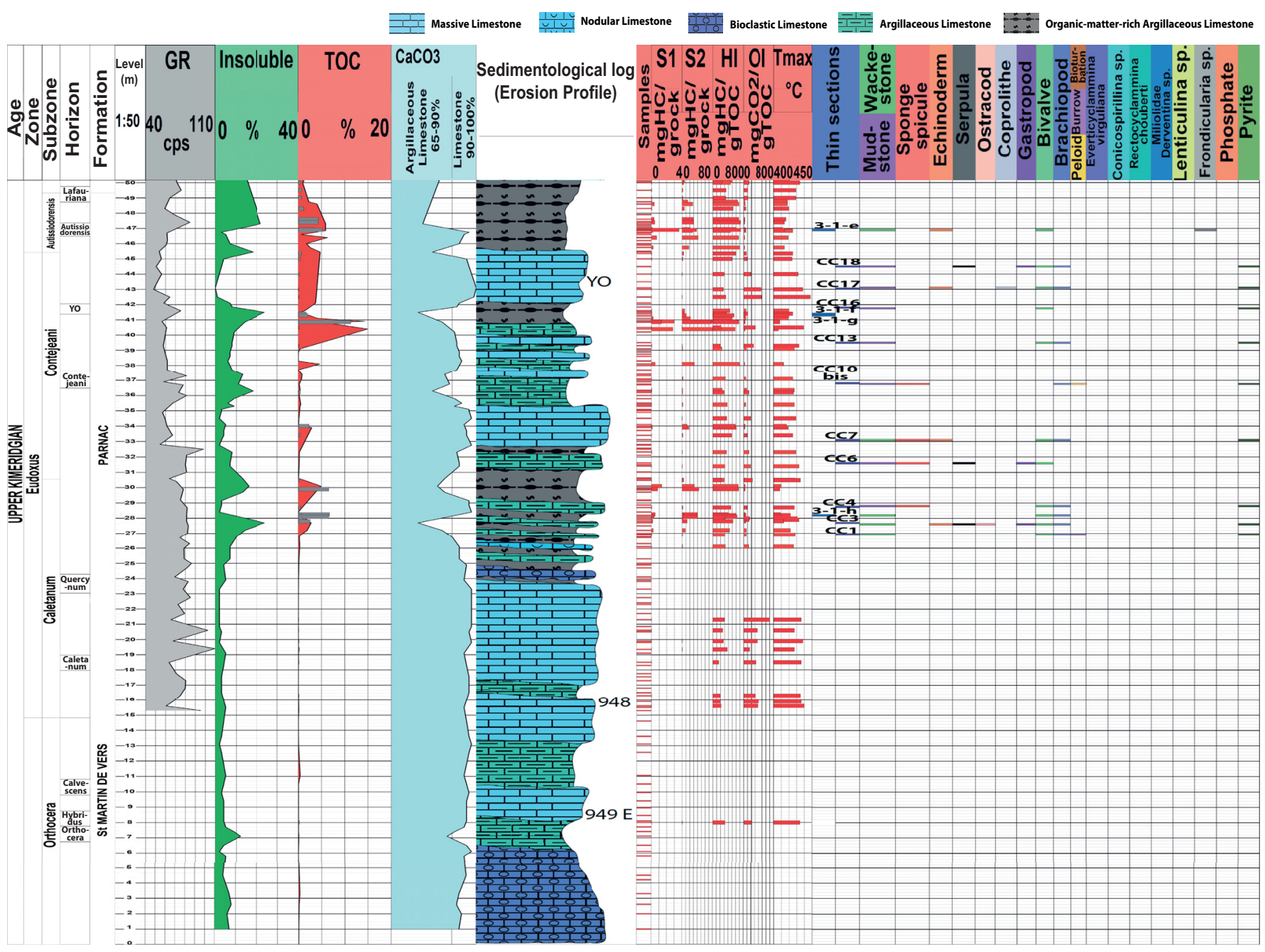

Fig. 5. Synthetic sedimentological log of Crayssac with gamma-ray, calcimetry, geochemistry data and the biostratigraphic wedge and fauna content (Parnac and St-Martin de Vers Formations).

in much lower proportions ( $\sim 6$ times less than illite). The second type ( 2 samples) is almost similar ( $\sim 98 \%$ calcite and $\sim 2 \%$ clay), except that it shows no swelling clays. The third type ( 2 samples) is also mainly composed of calcite, some quartz, and 4-5\% clay, but also shows the presence of equal amounts of chlorite and kaolinite in addition to illite + mica mixture.

\section{Interpretation}

\subsection{Depositional environments}

Both faunal associations and lithologies suggest that deposits of the Crayssac section were set up in an open marine environment. In detail, benthic foraminiferas-Everticyclammina virguliana, Rectocyclammina chouberti and Lenticulina sp. are characteristic of open outer shelf facies (e.g., Meyer, 2000), and have been previously interpreted to represent mid and outer ramp environments in the Quercy (Pélissié et al., 1984, Burchette and Wright, 1992). Epistomina sp., a plurilocular foraminifera, is also mainly found in open marine facies, associated with Lenticulina (e.g., Meyer, 2000). The hyaline formainifer Conicospirillina sp. is observed in outer lagoon facies and is regarded as a good marker of mid ramp facies (e.g., Meyer, 2000). Echinoderms are mainly represented by plates or sea-urchin radioles that are generally rare in the proximal facies, and usually represent a good marker of open environment (e.g., Meyer, 2000). The same interpretation has been proposed in the Quercy, where benthic foraminifera with hyaline test, brachiopods, serpula and sponge spicules would be characteristic of an outer ramp environment (Pélissié et al., 1984), and ostracods, gastropods, bivalves, and echinoderms of inner and mid ramp environments. This fauna, along with the lack of sedimentary structures related to wave dynamics, suggests that the Parnac Formation was deposited in an open marine homoclinal ramp (Pélissié, 1982; Burchette and Wright, 1992; Flügel, 2004) (Fig. 9). This is coherent with the Upper Kimmeridgian transgressive trend, which was accompanied by a large homogenization of lithologies at the scale of the entire Quercy area (Cubaynes et al., 1989). Indeed, the Salviac Formation, of Tithonian age, shows the same faunal content and a similar absence of sedimentary structures related to wave dynamics, compatible with open subtidal depositional environment (Pélissié, 1982; Burchette and Wright, 1992; Flügel, 2004). 

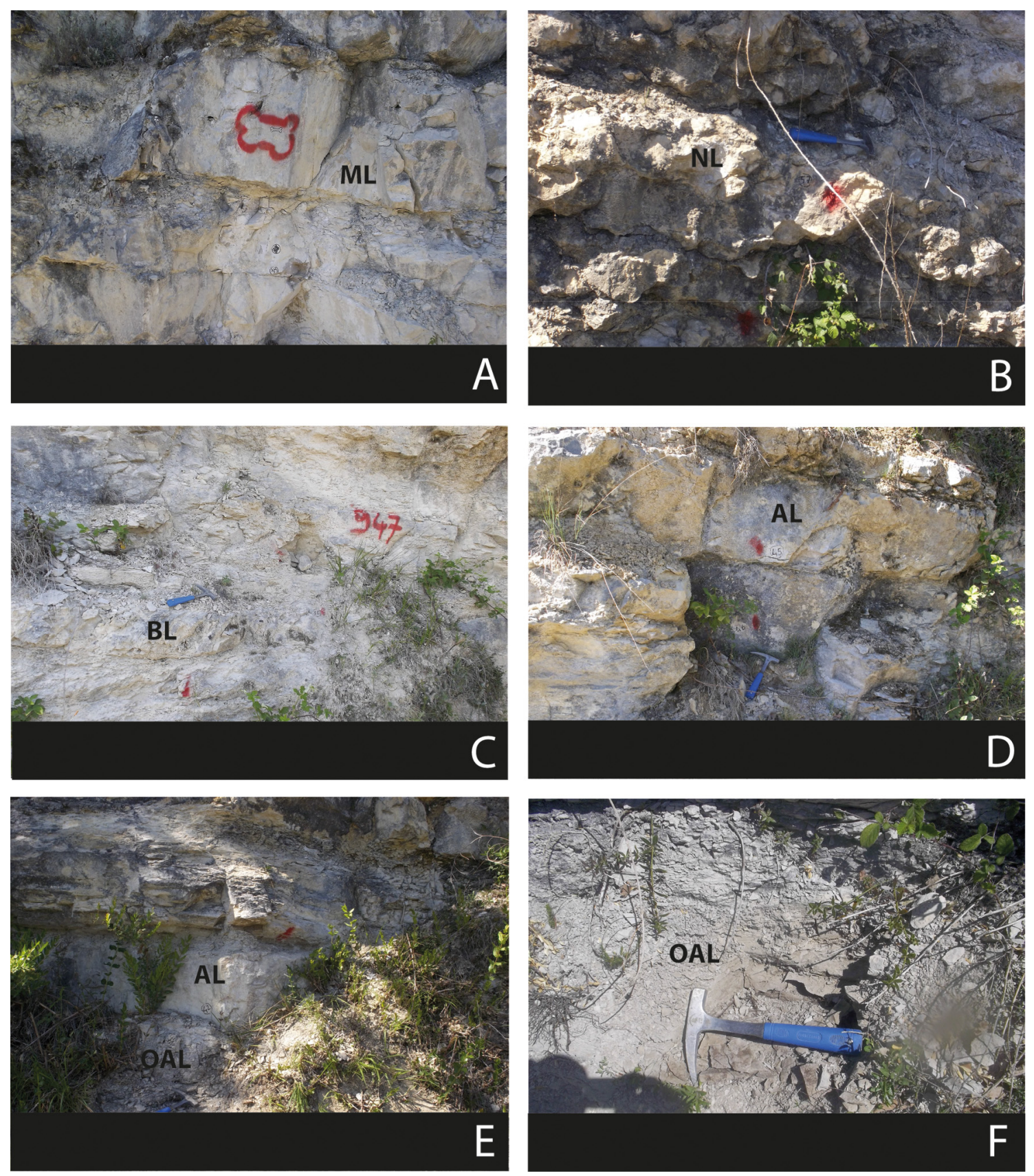

Fig. 6. Macroscopic observations of each facies. (A) Massive limestone (ML), (B) Nodular Limestone (NL), (C) Bioclastic Limestone (BL), (D) Argillaceous Limestone (AL), (E) Argillaceous Limestone and Organic matter-rich Argillaceous Limestone (OAL), (F) Organic matter-rich Argillaceous Limestone).

Taking into account variations of faunal associations according to lithofacies, we suggest that massive and bioclastic limestones were deposited on the inner ramp, above the fair weather wave base (Fig. 9). The nodular limestone is interpreted to have set up in the mid ramp, alternating with the argillaceous limestone (Fig. 9). For the argillaceous limestone facies, the fine-grained texture and the large presence of clays, along with the faunal content, suggest that deposition occurred in a low-energy environment, below the fair weather wave base, between the mid and the outer ramp (Fig. 9). Finally, in the case of organic-rich argillaceous limestones, the fine-grained texture, the presence of mud and fine laminations suggest that deposition took place in a lowenergy environment below the storm wave base, corresponding to the outer ramp (Fig. 9).

\subsection{Sequence stratigraphy}

This study shows a close link between lithofacies and biofacies on the Crayssac section. Thus, two sequence stratigraphic interpretations (Fig. 10) have been proposed using each criterion (lithology and faunal association) 

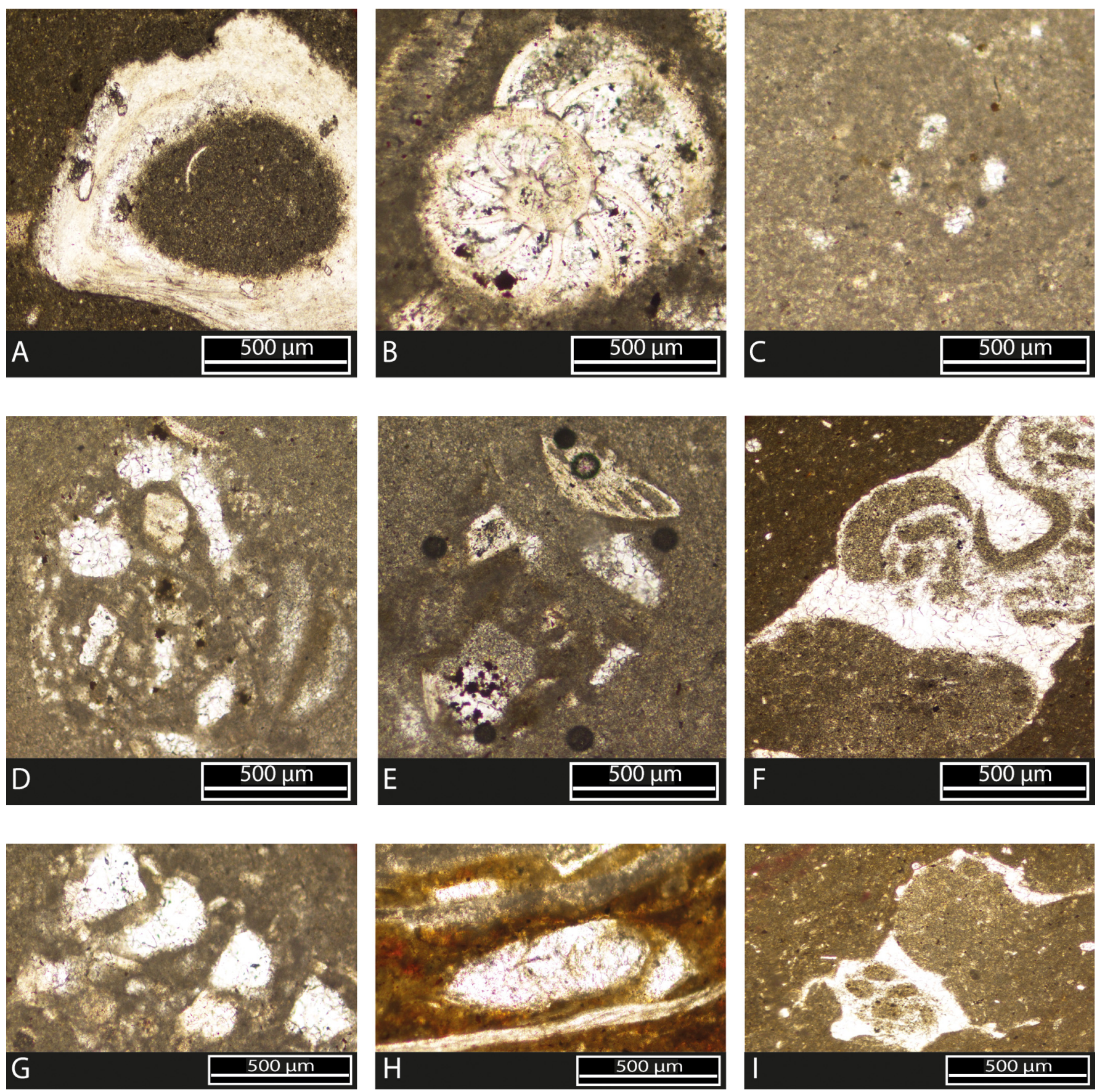

Fig. 7. Microfacies images by petrographic microscope of Crayssac outcrop samples. (A) Serpula, (B) Benthic Foraminifera with hyaline test, Lenticulina sp., (C) Coprolithe, Palaxius salataensis, equatorial section, (D) Benthic Foraminifera with agglutinated test, Everticyclammina virguliana, (E) Benthic Foraminifera with agglutinated test, Conicospirillina sp., (F) Trace of Gastropod, Presence of an internal filling; (G) Benthic Foraminifera with agglutinated test, Rectocyclammina chouberti, (H) Benthic Foraminifera with hyaline test, Fondicularia sp., (I) Peloidal and sparitic filling of a burrow.

independently. The sequential model deduced from the faunal content is primarily based on paleoenvironmental significance of each faunal assemblage and the presence of echinoderms and foraminifera with hyaline test. The presence of echinoderms reflects a more restricted environment while the loss of these expresses a deepening (Pélissié, 1982; Burchette and Wright, 1992; Flügel, 2004). Foraminifera indicate a more open marine environment. From these observations, it has also been possible to highlight four transgressive-regressive cycles.

For the lithofacies sequence model, several MFS are proposed based on the highest values of the gamma-ray and proportion of insolubles. According to this interpretation, sequence boundaries correspond to the contact between massive limestone and clay layers. From bottom to top, a regression followed by four transgressive-regressive cycles are 

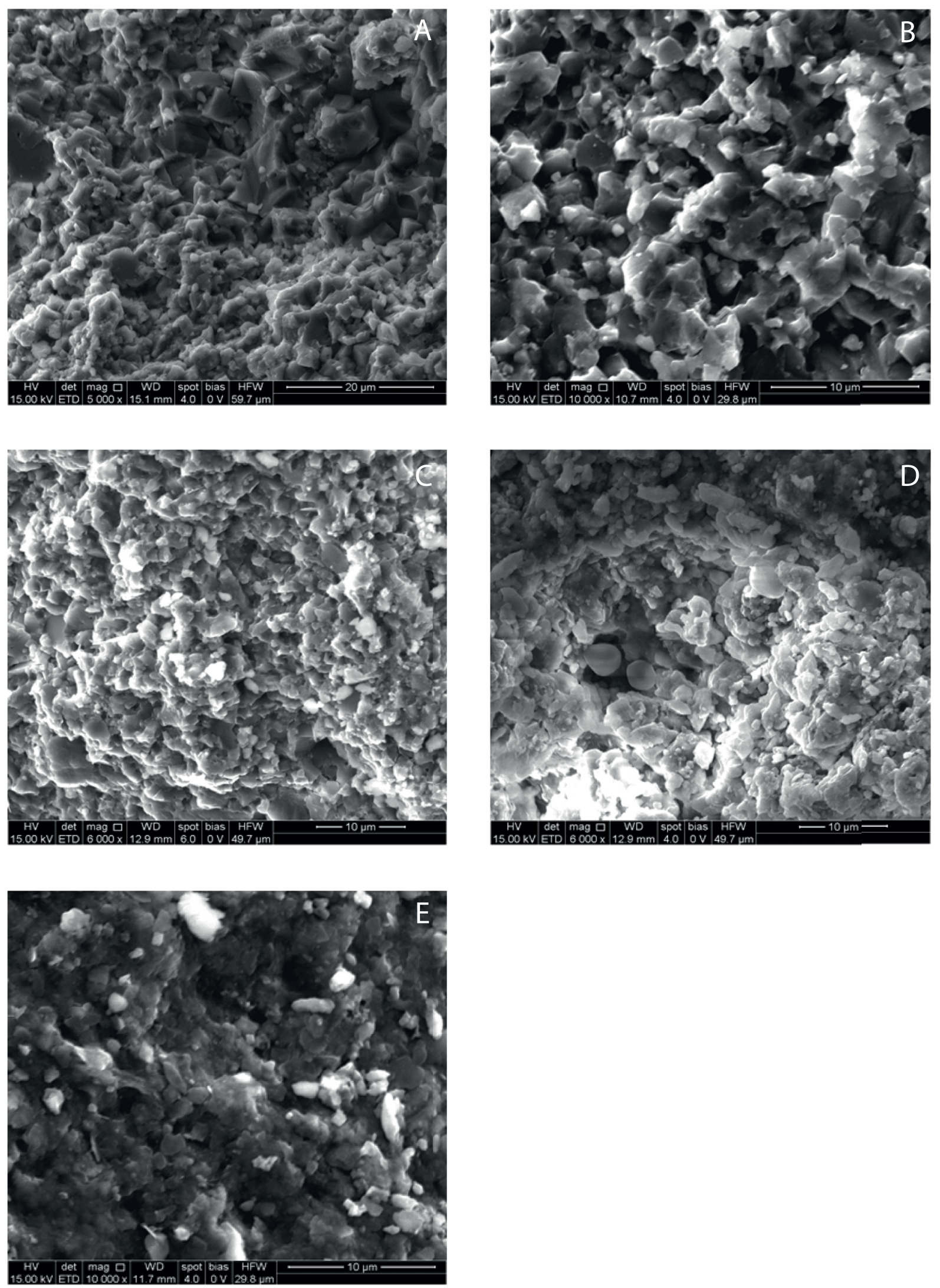

Fig. 8. SEM images of Crayssac outcrop samples. (A) Sample 3-1-a, (B) Sample 3-1-b), (C) Sample 3-1-c, (D) Sample 3-1-d, (E) Sample 3-1-e. 


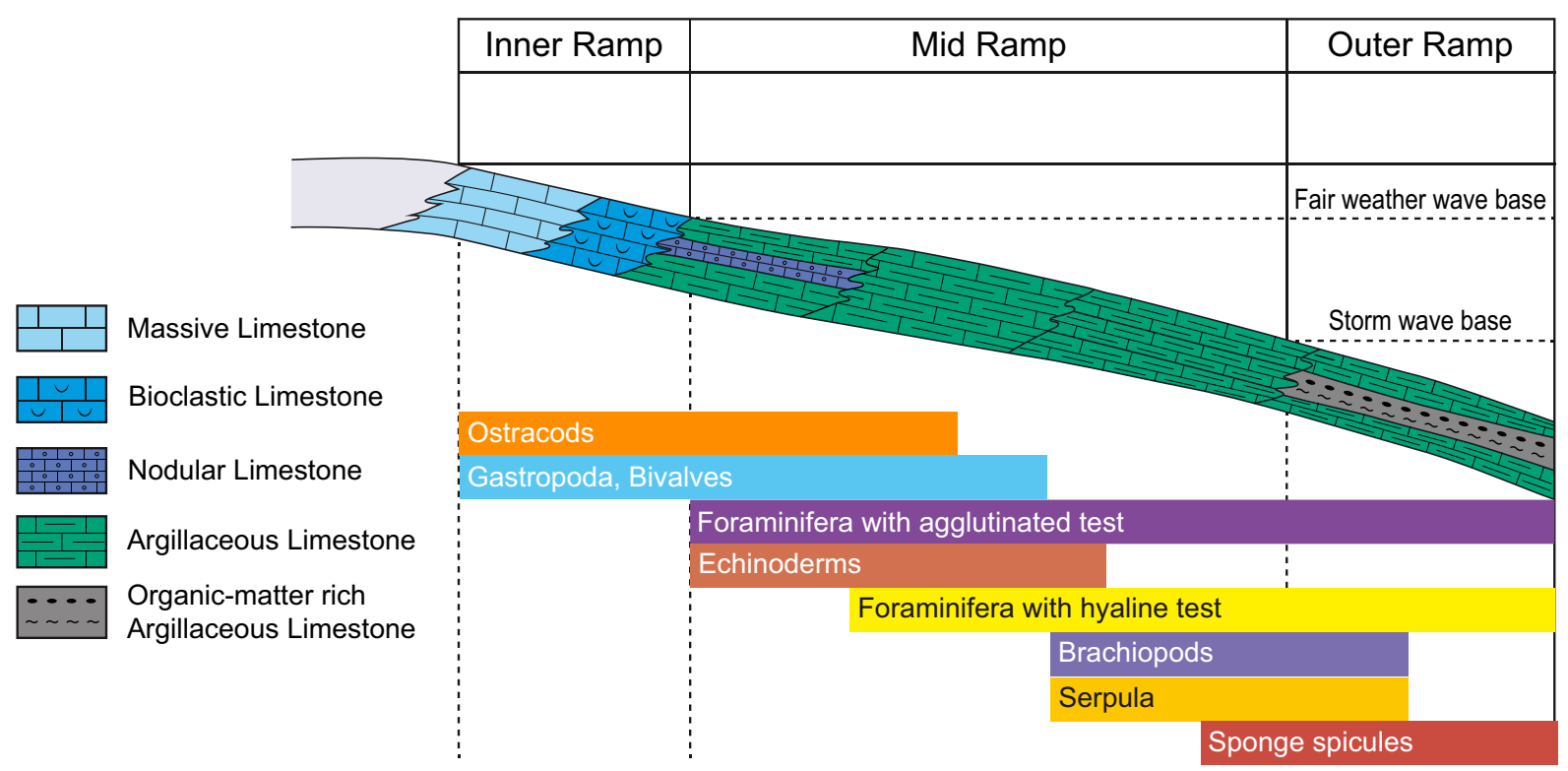

Fig. 9. Non-rimmed carbonate shelf type deposition model.

observed. They are in good accordance with the changes between different paleoenvironments (Inner Ramp, Mid Ramp, and Outer Ramp) identified on the basis of faunal associations. Indeed, the transition between a transgressive to a regressive trend corresponds to the transition to a more restricted environment. Conversely, the establishment of a transgressive trend implies deepening. In detail, from 0 to $24 \mathrm{~m}$, there is a large regression corresponding to the evolution from mid and outer ramp environments (nodular and argillaceous limestone) to inner ramp environments (massive limestone). From 24 to $35 \mathrm{~m}$, a first transgressive-regressive cycle is defined as follows: the transgressive interval corresponds to the transition from the mid ramp (nodular limestone) to the outer ramp (argillaceous limestone), while the regression interval is characterized by the evolution between the outer ramp (organic matter-rich argillaceous limestone) to the inner ramp (massive limestone). Two additional transgressive-regressive cycles are defined from 35 to $45 \mathrm{~m}$, and from 45 to $56 \mathrm{~m}$. From 56 to $77 \mathrm{~m}$, a transgression is described by the transition from inner ramp (massive limestone) to outer ramp (organic matter-rich argillaceous limestone), followed by the regression corresponding to the evolution between the outer ramp and the inner ramp. This sequence model corresponds fairly well to the model deduced from the faunal. In comparison, the sequence chronostratigraphic chart of Hardenbol et al. (1998) shows that there are two regressive-transgressive cycles in the Eudoxus Zone, one regressive-transgressive cycle in the Autissiodorensis Zone and one regressive-transgressive cycle in the Gigas Zone.

\subsection{Interpretation of geochemical data}

The pseudo Van Krevelen diagram representing HI versus OI shows that in the studied SR (organic-matter-rich argillaceous limestone), kerogen is of type II and immature (Fig. 11). This indicates that organic matter is probably derived from marine algae or cyanobacteria (Espitalié et al., 1985).

\section{Discussion}

\subsection{Origin of organic matter preservation in the Parnac and St-Chamar and Formation carbonate source rock}

During the Kimmeridgian, the opening of the North Atlantic Ocean which was concomitant to the south-eastward drift of the Africa South America megablock (Cecca et al., 1993; De Wever and Baudin, 1996). The Arabian Peninsula movement from the equatorial belt to the tropical arid zone induced the deposition of marine organic-carbon rich facies (De Wever and Baudin, 1996). In the meantime, Eurasia moved from the temperate humid area to the north tropical belt and this location allowed the deposition in the Paris basin of marine organic-carbon rich facies (De Wever and Baudin, 1996). On the other hand, during the Kimmeridgian marine connections between the Tethyan, Central Atlantic and Arctic Ocean were developed (Churkin and Trexler, 1981; Vogt et al., 1981; Birkenmajer et al., 1982; Oschmann, 1988) including shallow water connections from the Arctic Ocean southward via the Volga-Ural Strait, Western Siberia, East Siberia, Alaska and the North Atlantic Shelf Sea (Hallam, 1975; Barron et al., 1980, 1981; Churkin and Trexler, 1981).

In the western Tethysian domain, the Kimmeridgian and the early Tithonian were marked by the widespread deposition of organic-rich deposits, in link with the major transgressive trend observed at that time (Herbin and Geyssant, 1993), and followed by a rapid decrease of organic carbon accumulation during the late Tithonian (Baudin, 1995; Frakes et al., 2005). Examples include organic-rich shales such as the Kimmeridge Clay in the UK, North Sea and Western Siberia (Hantzpergue et al., 1998; Frakes et al., 2005). Detailed stratigraphy of Upper Kimmeridgian/Tithonian deposits of southern England (UK) and of the Boulonnais (France) regions has identified 2 to 3 organic-rich sequences, the two lattest respectively corresponding to the transition between the Eudoxus and 


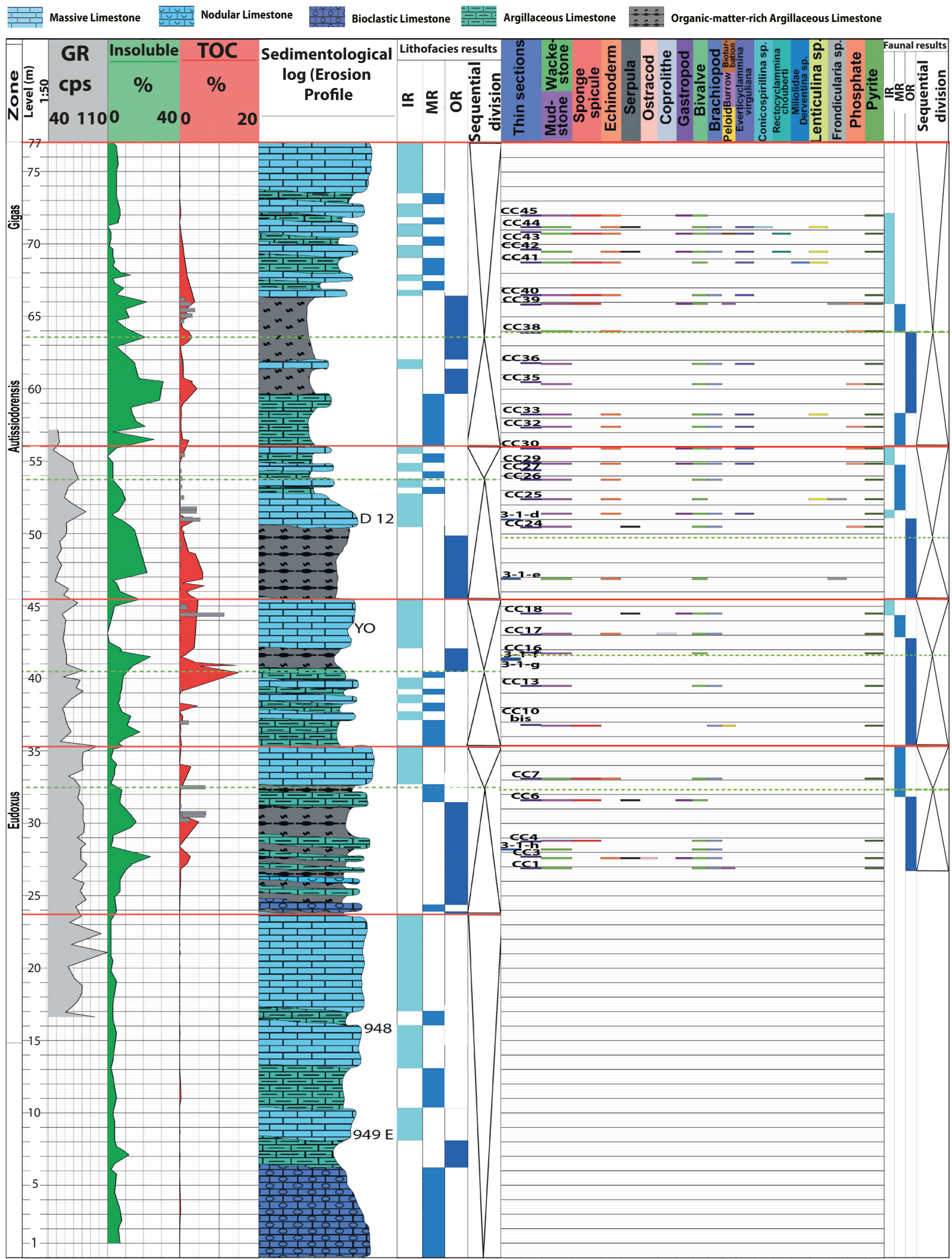

Fig. 10. Sequential model based on lithofacies of Crayssac log and sequential model deducted from the faunal content examined in thin sections of Crayssac outcrop samples. The depositional environment is represented in different colours of blue as inner ramp (IR: light blue), mid ramp (MR: medium blue), outer ramp (OR: dark blue). Sequences boundaries are in red and the Maximum Flooding Surface (MFS) in light green. 


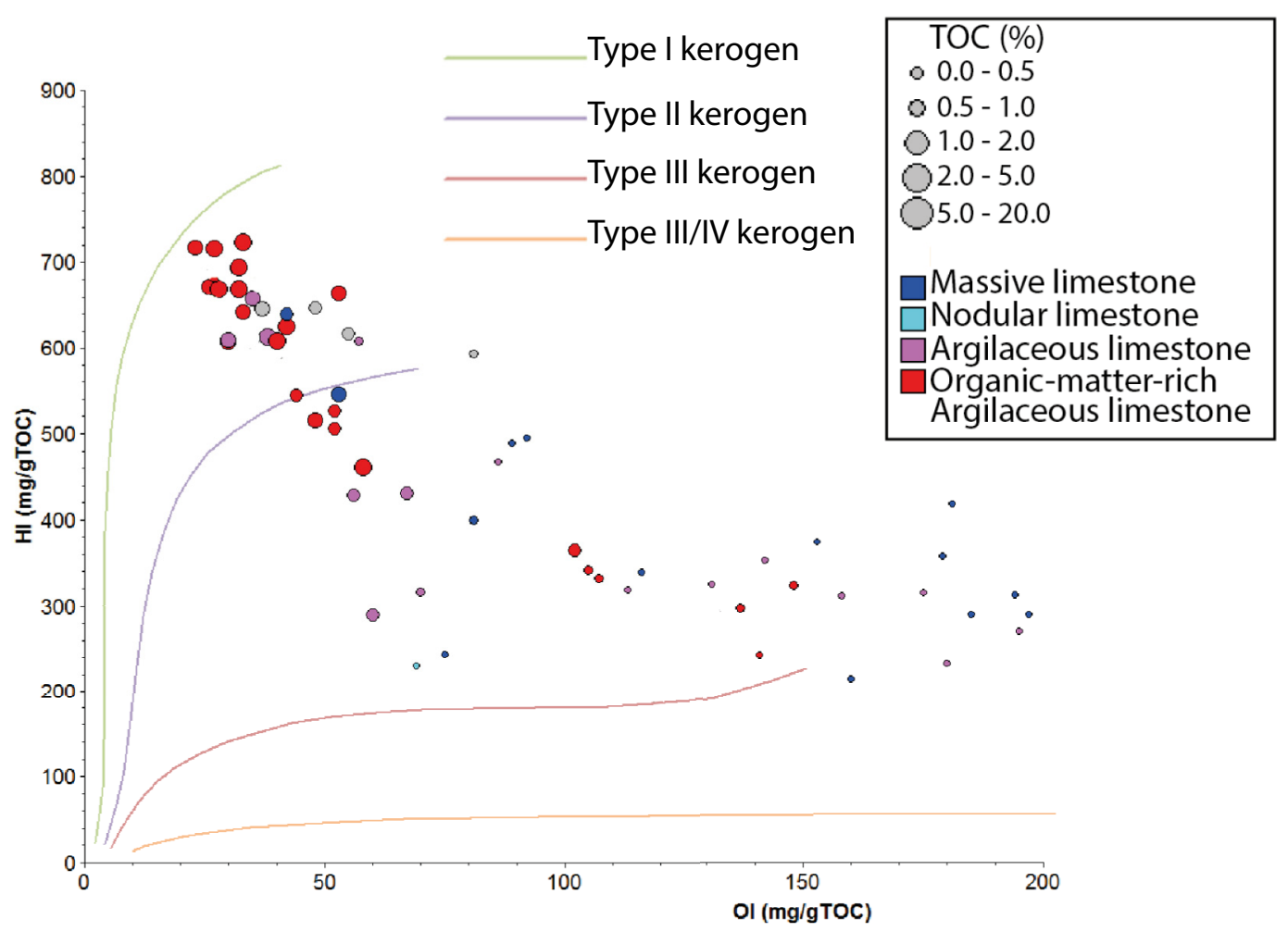

Fig. 11. Pseudo Van Krevelen representing HI versus OI.

the Autissiodorensis ammonite zones (Upper Kimmeridgian), and to the Gigas-Elegans ammonite zones (Tithonian) (Herbin and Geyssant, 1993). Ammonite biozonation of the Crayssac section (Hantzpergue, 1987) shows similar ages for organic-rich intervals (Figs. 4 and 5), suggesting that the conditions required for their deposition have been reached simultaneously on the entire West-European platform, including the Quercy. This calls for large scale changes in environmental conditions rather than local perturbations of the carbon cycle. In western Europe, the Kimmeridgian generally corresponded to a hot and humid climate (Abbink et al., 2001, Brigaud et al., 2008) followed by a transition to more arid climate throughout the Tithonian (Abbink et al., 2001; Riboulleau et al., 2003; Schnyder et al., 2005, 2009). Climate has an important influence on primary productivity, production of anoxia and carbon burial (e.g., Bordenave, 1993; Frakes et al., 2005). Whether organic matter accumulation is ruled by important primary productivity or by anoxic conditions, which help preserving organic matter, has been a long-standing matter of debate (e.g., Pedersen and Calvert, 1990; Bordenave, 1993). In the Kimmeridgian of northwestern Europe, primary productivity has likely been fuelled by monsoonal conditions, involving important fluvial discharges in the Tethys Ocean (Martinez and Dera, 2015; Armstrong et al., 2016). Accordingly, high planktonic production is inferred to have been the main driver of organic matter accumulation in distal platforms, while local development of anoxic conditions could further enhance preservation (e.g., Disnar and Ramanampisoa, 1995; LallierVergès et al., 1995).
Although further work is needed to constrain more precisely the origin of organic matter accumulation, we suggest by analogy that this scenario also took place in the Quercy area. The presence of bivalves and foraminifera in several beds of organic-rich argillaceous limestones indicate, however, that anoxic conditions were probably not reached.

Another important parameter that controls organic matter preservation is sedimentation rate (Müller and Suess, 1979). High sedimentation rates tend to enhance preservation by rapidly removing organic carbon from the oxic zone (Müller and Suess, 1979). In the Crayssac section, sedimentation rates of organic-rich intervals of the Parnac and St-Chamarand Formations can be calculated from ammonite biozonations. The first interval (from 24 to $32.5 \mathrm{~m}$ ) includes the Caletanum Subzone (of a $240 \mathrm{ka}$ duration [Gradstein et al., 2012]), which corresponds to a sedimentation rate of $6.7 \mathrm{~cm} / \mathrm{k}$.y (uncorrected from compaction). The second interval (from 40.8 to $42 \mathrm{~m}$ ) is located in the Contejeani Subzone (of a $130 \mathrm{ka}$ duration [Gradstein et al., 2012]), which leads to a mean sedimentation rate of $11.7 \mathrm{~cm} / \mathrm{k} . \mathrm{y}$. The two other organic-rich intervals (from 45.3 to $50.5 \mathrm{~m}$ and from 59.5 to $66 \mathrm{~m}$ ) are observed within the Autissiodorensis Subzone. This ammonite zone has a duration estimated as $450 \mathrm{ka}$ duration (Gradstein et al., 2012), corresponding to a mean sedimentation rate of $5.1 \mathrm{~cm} / \mathrm{k} . \mathrm{y}$. These values fall in the moderately rapid sedimentation rates of Müller and Suess (1979), corresponding to 0.1 to $2 \%$ of primary produced organic carbon preserved in the sediments. Provided primary production is important, such values are high enough to form organic-rich sediments (TOC $>1 \%$ ) (Müller and Suess, 1979). 


\subsection{Is the Parnac Formation a good analogue to Middle East organic-rich carbonates of the Hanifa Formation?}

Our results show that the Parnac Formation is composed of a succession of limestones, argillaceous limestones and organic-matter-rich argillaceous limestones, which can petrographically defined as mudstones and wackestones. These lithologies are quite similar to those of the Upper Jurassic (Upper Oxfordian/ Lower Kimmeridgian) Hanifa Formation of the Arabian Peninsula. The Hanifa Formation primarily consists of organic-rich argillaceous limestone (Gotnia Basin) that evolves laterally into calcareous shale (Qatar Arch) (Poppelreiter et al., 2012), and includes alternations between laminated, organic-rich mudstones and bioturbated mudstones or wackestones (Droste, 1990). In addition, organic-rich intervals of the Hanifa Formation, which constitute one of the most important hydrocarbon SR of the Middle East oil (Murris, 1980), have geochemical characteristics comparable to the Parnac Formation (TOC of 5-15\%, type II kerogen, high generation potential) (Droste, 1990).

Similarities are also found in terms of sequence stratigraphy. The Hanifa Formation corresponds to a major transgressive-regressive cycle including two transgressiveregressive subcycles, controlled by regional relative sea-level change (Droste, 1990). Organic-rich carbonates were deposited in the lower transgressive parts of each subcycle, whereas prograding bioturbated wacke/packstones constitute the upper regressive part. These two subcycles are defined as two depositional sequences where the maximum flooding surfaces are associated with maximum organic carbon contents (Droste, 1990). In the major sequence, the SR interval occurred in the upper part of the transgressive system tract. An almost similar configuration is found in the Parnac Formation, which consists of two transgressive-regressive cycles comprised in a major transgressive sequence (Droste, 1990). In addition, the maximum flooding surfaces also correspond to peaks of high organic content in the argillaceous carbonates (Droste, 1990).

However, despite these lithological and stratigraphical similarities, depositional environments and conditions of organic matter accumulation and preservation appear to differ between the two Formations. First, the Hanifa Formation was deposited in an intraplatform depression, formed by differential subsidence of the platform interior during rapid sea-level rise (Murris, 1980). Accordingly, the fine-grained texture, the presence of mud and laminations all indicate deposition below fair-weather wave base, as the depression was enclosed by a wide, epeiric, shallow-water carbonate platform (Droste, 1990). By comparison, the Parnac Formation was deposited in an open shelf likely corresponding to a carbonate ramp. Sedimentary structures also suggest, however, that deposition of pelagic carbonates, including organic-rich ones, mainly occurred below the fair-weather wave base, favored by rapid Kimmeridgian transgression. Second, in the Hanifa Formation restricted circulation in the intraplatform depression was prone to the development of anoxic conditions, as shown by the absence or limited presence of benthic fauna, thereby leading to an exceptional preservation of marine organic matter (Myers, 2009). In contrast, strong anoxic conditions have not been identified in the Parnac Formation, where bioclasts are present in the organic-matter-rich argillaceous limestones. By analogy with other Upper Kimmeridgian SR of western Europe, it seems that organic matter preservation was mainly controlled by a strong primary productivity rather than by extensive anoxic conditions. It should be noted, however, that evidences of active upwelling currents have been demonstrated both in northern Tethys and close to the Arabian platform during the Jurassic (Dercourt et al., 1994; Golonka and Krobicki, 2012). Not only those currents did favour plankton production, but they also were at the origin of the development of widespread anoxic episodes during the Kimmeridgian (Baudin, 1995).

\section{Conclusion}

During this work, a sedimentological, mineralogical and geochemical study was conducted including analysis of microfacies (petrographic microscope and SEM), XRD, calcimetry, and Rock Eval to better understand carbonate source-rock deposition and preservation. Although the section of the Parnac and St-Chamarand Formations is highly carbonated, with $\% \mathrm{CaCO}_{3}>65 \%$, some intervals of the section show high TOC content, which can reach $15 \%$. The organic matter is type II and immature. The deposition system of this SR is with an algal type organic matter. Based on analyses of lithofacies and fauna, the depositional environment of this section is attributed to a homoclinal ramp. Organic matter of this formation is concentrated in the mid ramp alternating with argillaceous limestones.

The Parnac Formation appears to be a potential analogue of the Hanifa Formation. The deposition system of the Hanifa Formation was an intra-platform basin in shallow marine environment below wave base, whereas The Parnac Formation $\mathrm{SR}$ is interpreted to have been deposited in an open marine environment within a homoclinal ramp (outer ramp), below storm wave base. The two SR intervals of each formation took place during high sea-level rise and hence through the transgressive sequence. The Parnac Formation is composed of two transgressive-regressive cycles, whereas the Hanifa Formation is defined by two low-order transgressive-regressive cycles within one major transgressive-regressive cycle. Finally, these two carbonate SR have both strong petroleum potential.

Acknowledgements. The authors would like to thank Bertrand Fasentieux for the production of thin sections. We would like to express our gratitude to Dr. Alexander Brasier for his contribution to this manuscript. Olivier Ridet and Maryline Castello are acknowledged for their participation to field campaigns. We also thank Frank Haeseler, Claire Fialips and Pierre Hantzpergue for fruitful discussions. This manuscript greatly benefited from the remarks of two anonymous reviewers.

\section{References}

Abbink O, Targarona J, Brinkhuis H, Visscher H. 2001. Late Jurassic to earliest Cretaceous palaeoclimatic evolution of the southern North Sea. Global and Planetary Change 30 (3): 231-256. 
Alsharhan AS, Magara K. 1994. The Jurassic of the Arabian Gulf Basin: Facies, depositional setting and hydrocarbon habitat. Pangea: Global Environment and Resources. Canadian Society of Petroleum Geologists Memoir 17: 397-412.

Armstrong HA, Wagner T, Herringshaw LG, Farnsworth AJ, Lunt DJ, Harland M, et al. 2016. Hadley circulation and precipitation changes controlling black shale deposition in the Late Jurassic Boreal Seaway. Paleoceanography 31: 1041-1053.

Astruc JG, Bruxelles L, Ciszak R. 2008. La série stratigraphique des Causses du Quercy. Journées AFK/AGSO/CFH 5: 6-8.

Barron E, Sloan II JL, Harrison CG. 1980. Potential significance of land sea distribution and surface albedo variations as climatic forcing factor; 180 m.y. to the present. Palaeogeography, Palaeoclimatology, Palaeoecology 30: 17-40.

Barron EJ, Harrison CG, Sloan II JL, Hay WW. 1981. Paleogeography, 180 million years ago to the present. Eclogae Geologicae Helvetiae 74: 443-470.

Baudin F. 1995. Depositional controls on the Mesozoic source rocks in the Tethys. AAPG Studies in Geology, Tulsa 40: 191-211.

Beydoun ZR. 1986. The petroleum resources of the Middle East: a review. Journal of Petroleum Geology 9 (1): 5-27.

Bilotte M. 1995. Le Bassin d'Aquitaine. Évolution sédimentaire et structurale. Toulouse, 7 : Laboratoire de Géologie sédimentaire et Paléontologie, Université Paul Sabatier.

Birkenmajer K, Pugazewska H, Wierzbowski A. 1982. The Janusfjellet Formation (Jurassic-Lower Cretaceous) at Myklegardfjellet, east Spitsbergen. Acta Palaeontologica Polonica 43: 107-140.

Biteau JJ, Le Marrec A, Le Vot M, Masset JM. 2006. The Aquitaine Basin. Petroleum Geoscience 12 (3): 247-273.

Bordenave ML. 1993. The sedimentation of organic matter. In: Bordenave ML, ed. Applied Petroleum Geochemistry. Paris: Éditions Technip, pp. 15-76.

Brigaud B, Puceat E, Pellenard P, Vincent B, Joachimski MM. 2008. Climatic fluctuations and seasonality during the Late Jurassic (Oxfordian-Early Kimmeridgian) inferred from $\delta 18$ O of Paris Basin oyster shells. Earth and Planetary Science Letters 273 (1): 58-67.

Burchette TP, Wright VP. 1992. Carbonate ramp depositional systems. Sedimentary Geology 79 (1-4): 3-57.

Bureau de recherches géologiques et minières. 1986. Aperçu de la géologie du Bassin Aquitain. Synthèse ANDRA-BRGM.

Canerot J, Lenoble JL. 1989. Le diapir du Lichançumendy (PyrénéesAtlantiques), nouvel élément de la marge ibérique des Pyrénées occidentales. Comptes rendus de l'Académie des Sciences. Série 2, Mécanique, Physique, Chimie, Sciences de l'univers, Sciences de la Terre 308 (16): 1467-1472.

Cecca F, Azema J, Fourcade E, Baudin F, Guiraud R, Bonneau M, et al. 1993. Early Kimmeridgian palaeoenvironments. In: Dercourt J, Ricou LE, Vrielynck B, eds. Atlas Tethys palaeoenvironmental maps. Maps. Rueil-Malmaison: BEICIP-FRANLAB.

Churkin MJ, Trexler JH. 1981. Continental plates and accreted oceanic terranes in the Arctic. The Arctic Ocean. New York: Plenum Press, pp. 1-20.

Cubaynes R, Faure P, Hantzpergue P, Pelissie T, Rey J. 1989. Le Jurassique du Quercy: unités lithostratigraphiques, stratigraphie et organisation séquentielle, évolution sédimentaire. Géologie de la France 3: 33-62.

Cubaynes R, Hantzpergue P, Lezin C. 2004. Les dépôts littoraux du jurassique sur la bordure quercynoise (Aquitaine): généralités. Livret-guide d'excursion. Toulouse: Laboratoire de Géologie sédimentaire et paléontologie de l'Université Paul Sabatier, vol. 42.

De Périère MD, Durlet C, Vennin E, Lambert L, Bourillot R, Caline B, et al. 2011. Morphometry of micrite particles in cretaceous microporous limestones of the Middle East: Influence on reservoir properties. Marine and Petroleum Geology 28 (9): 1727-1750.

De Wever P, Baudin F. 1996. Paleogeography of radiolarite and organic-rich deposits in Mesozoic Tethys. Geologische Rundschau 85: $310-326$.

Delfaud J. 1969. Essais sur la géologie dynamique du domaine aquitano-pyrénéen durant le Jurassique et le Crétacé inférieur. Thèse de Doctorat d'État, Université de Bordeaux.

Dera G, Prunier J, Smith PL, Haggart JW, Popov E, Guzhov A, et al. 2015. Nd isotope constraints on ocean circulation, paleoclimate, and continental drainage during the Jurassic breakup of Pangea. Gondwana Research 27 (4): 1599-1615.

Dercourt J, Fourcade E, Cecca F, Azema J, Enay R, Bassoullet JP, et al. 1994. Palaeoenvironment of the Jurassic system in the Western and Central Tethys (Toarcian, Callovian, Kimmeridgian, Tithonian): An overview. Geobios 27: 625-644.

Disnar JR, Ramanampisoa L. 1995. Palaeoproduction control on anoxia and organic matter preservation and accumulation in the Kimmeridge Clay Formation of Yorkshire (GB): molecular assessment. In: Organic Matter Accumulation. Berlin Heidelberg: Springer, pp. 49-62.

Droste H. 1990. Depositional cycles and source rock development in an epeiric intra-platform basin: the Hanifa Formation of the Arabian peninsula. Sedimentary Geology 69 (3): 281-296.

Espitalié J, Madec M, Tissot B, Leplat P. 1977. Source rock characterization method for petroleum exploration. Proceedings of the Offshore Technology Conference, Maggio 2-5, Houston, TX, pp. 439-444.

Espitalié J, Madec M, Leplat P, Paulet J. 1985. Method and device for determining the organic carbon content of a sample. U.S. Patent 4: $519,983$.

Flügel E. 2004. Microfacies of carbonate rocks: analysis, interpretation and application. Berlin: Springer.

Frakes LA, Francis JE, Syktus JI. 2005. Climate modes of the Phanerozoic. Cambridge: Cambridge University Press.

Golonka J, Krobicki M. 2012. Upwelling regime in the Carpathian Tethys: a Jurassic-Cretaceous palaeogeographic and paleoclimatic perspective. Geological Quarterly 45 (1): 15-32.

Gradstein FM, Ogg JG, Schmitz M, Ogg G. 2012. The geologic time scale 2012. Amsterdam: Elsevier, vol. 2.

Hallam A. 1975. Jurassic Environments. Cambridge: Cambridge University Press.

Hantzpergue P. 1987. Les ammonites kimmeridgiennes du haut-fond d'europe occidentale (perisphinctidae, aulacostephanidae et aspidoceratidae) : biochronologie, systématique, évolution, paléobiogéographie. Thèse de Doctorat, Université de Poitiers.

Hantzpergue P, Lafaurie G. 1983. Le Kimméridgien quercynois : un complément biostratigraphique du Jurassique supérieur d'Aquitaine. Geobios 16 (5): 601-611.

Hantzpergue P, Baudin F, Mitta V, Olferiev A, Zakharov V. 1998. The Upper Jurassic of the Volga basin: ammonite biostratigraphy and occurrence of organic-carbon rich facies. Correlations between Boreal-Subboreal and Submediterranean Provinces. In: CrasquinSoleau S, Barrier E, eds. Peri-Tethys Memoir 4: Epicratonic basins of Peri-Tethyan Platforms. Mém Muséum natn Hist Nat 179: 9-33.

Hardenbol J, Thierry J, Farley MB, Jacquin T, De Graciansky PC, Vail PR. 1998. Appendix To: Mesozoic and Cenozoic Sequence Chronostratigraphic Framework of European Basins. Special Publication-SEPM 60: 763-781.

Harris PMM, Katz BJ. 2005. Carbonate mud and carbonate source rocks. Calgary (Canada): AAPG.

Herbin JP, Geyssant JR. 1993. Ceintures organiques au Kimméridgien/Tithonien en Angleterre (Yorkshire, Dorset) et en France (Boulonnais). Comptes rendus de l'Académie des sciences. Série 2, 
Mécanique, Physique, Chimie, Sciences de l'univers, Sciences de la Terre 317 (10): 1309-1316.

Huret E. 2006. Analyse cyclostratigraphique des variations de la susceptibilité magnétique des argilites callovo-oxfordiennes de l'Est du Bassin de Paris : application à la recherche de hiatus sédimentaires. Thèse de Doctorat, Université Pierre et Marie Curie-Paris 6.

Lallier-Vergès E, Bertrand P, Tribovillard N, Desprairies A. 1995. Short-term organic cyclicities from the Kimmeridge Clay Formation of Yorkshire (GB): combined accumulation and degradation of organic carbon under the control of primary production variations. In: Organic Matter Accumulation. Berlin Heidelberg: Springer, pp. 3-13.

Lamas F, Irigaray C, Oteo C, Chacon J. 2005. Selection of the most appropriate method to determine the carbonate content for engineering purposes with particular regard to marls. Engineering geology 81 (1): 32-41.

Martinez M, Dera G. 2015. Orbital pacing of carbon fluxes by a 9-My eccentricity cycle during the Mesozoic. Proceedings of the National Academy of Sciences 112 (41): 12604-12609.

Meyer M. 2000. Le complexe récifal kimméridgien-tithonien du Jura méridional interne (France), évolution multifactorielle, stratigraphique et tectonique. Thèse de Doctorat. Faculté Sciences, Université de Genève.

Müller PJ, Suess E. 1979. Productivity, sedimentation rate, and sedimentary organic matter in the oceans. I. Organic carbon preservation. Deep Sea Research Part A. Oceanographic Research Papers 26 (12): 1347-1362.

Murris RJ. 1980. Hydrocarbon habitat of the Middle East. In: Miall $\mathrm{AD}$, ed. Facts and Principles of World Petroleum Occurrence. Calgary (Canada): CSPG Mem, vol. 6, pp. 1-1004.

Myers KJ. 2009. Organic rich facies and hydrocarbon source rocks. Sequence Stratigraphy 11: 238-257.

Oschmann W. 1988. Kimmeridge Clay sedimentation - a new cyclic model. Palaeogeography, Palaeoclimatology, Palaeoecology 65: 217-251.

Pedersen TF, Calvert SE. 1990. Anoxia vs. productivity: what controls the formation of organic-carbon-rich sediments and sedimentary rocks? AAPG Bulletin 74: 454-466.

Pélissié T. 1982. Le Causse jurassique de Limogne-en-Quercy: stratigraphie, sédimentologie, structure. Thèse $3^{\mathrm{e}}$ cycle. Toulouse : Université Paul Sabatier.

Pélissié T, Peybernes B, Rey J. 1984. Les grands foraminifères benthiques du Jurassique moyen/supérieur du sud-ouest de la France (Aquitaine, Causses, Pyrénées). Intérêt biostratigraphique, paléoécologique et paléobiogéographique. Benthos 83 (2): 479-489.

Pene F. 1956. Les Hydrocarbures dans le Bassin Aquitain. Bordeaux : Éditions Universitaires.

Poppelreiter MC, Kolkmann W, Hordijk H, Stevanovich M. 2012. Regional settings and characteristics of an Oxfordian hot shale. In: Fourth EAGE Workshop on Arabian Plate Geology.
Quirein JA, Gardner JS, Watson JT. 1982. Combined natural gammaray spectral litho-density measurements applied to clay mineral identification. AAPG Bulletin-American Association of Petroleum Geologists 66 (9): 1446-1446.

Riboulleau A, Baudin F, Daux V, Hantzpergue P, Renard M, Zakharov V. 1998. Évolution de la paléotempérature des eaux de la plateforme russe au cours du Jurassique supérieur. Comptes Rendus de l'Académie des Sciences, Paris, Sciences de la Terre et des Planètes 326: 239-246.

Riboulleau A, Baudin F, Deconinck JF, Derenne S, Largeau C, Tribovillard N. 2003. Depositional conditions and organic matter preservation pathways in an epicontinental environment: the Upper Jurassic Kasphir Oil Shales (Volga Basin, Russia). Palaeogeography, Palaeoclimatology, Palaeoecology 197 (3-4): 1-27.

Riboulleau A, Schnyder J, Riquier L, Lefevre V, Baudin F, Deconinck J-F. 2007. Environmental change during the Early Cretaceous in the Purbeck-type Durlston Bay section (Dorset, Southern England): a biomarker approach. Organic Geochemistry 38: 1804-1823.

Schmoker JW. 1981. Determination of organic-matter content of Appalachian Devonian shales from gamma-ray logs. $A A P G$ Bulletin 65 (7): 1285-1298.

Schnyder J, Gorin G, Deconinck JF, Baudin F, Soussi M. 2005. Enregistrement de la variation climatique du passage Jurassique/ Crétacé sur la marge sud de la Téthys : minéralogie des argiles et palynofaciès de la coupe du Jebel Meloussi en Tunisie (formation Sidi Kralif). Bulletin de la Société géologique de France 176 (2): 171-182.

Schnyder J, Baudin F, Deconinck JF. 2009. Occurrence of organicmatter-rich beds in Lower Cretaceous coastal evaporitic setting (Dorset, UK): a link to long-term palaeoclimate changes? Cretaceous Research 30: 356-366.

Schnyder J, Deconinck JF, Baudin F, Colombie C, Du Chene RJ, Gardin S, et al. 2012. Purbeck beds (Late Jurassic) in the Phare de Chassiron section (Île d'Oléron, NW Aquitaine Basin, France): Refined age-assignment and long-term depositional sequences. Geobios 45 (5): 485-499.

Serra O. 1979. Diagraphies différées. Bases de l'interprétation. Tome 1: Acquisition des données diagraphiques. Bulletin du Centre de Recherche Exploration-Production Elf-Aquitaine. Pau: Éditions Technip, vol. 328.

Vogt PR, Peery RK, Feden RH, Fleming HS, Cherkis NZ. 1981. The Greenland-Norwegian Sea and Iceland environment. Arctic Ocean. New York, N.Y.: Plenum Press, pp. 493-581.

Volery C, Davaud E, Durlet C, Clavel B, Charollais J, Caline B. 2010. Microporous and tight limestones in the Urgonian Formation (late Hauterivian to early Aptian) of the French Jura Mountains: focus on the factors controlling the formation of microporous facies. Sedimentary Geology 230 (1): 21-34.

Cite this article as: Bastianini L, Caline B, Hoareau G, Bonnel C, Martinez M, Lézin C, Baudin F, Brasier A, Guy L. 2017. Sedimentary characterization of the carbonate source rock of Upper Kimmeridgian Parnac Formation of the Aquitaine Basin (Quercy area), Bull. Soc. géol. Fr. 188: 32. 